\title{
Tree-Fall Gaps Effects on Spider (Araneae) Assemblages in an Atlantic Forest Landscape in Northeastern Brazil
}

\author{
Marcelo Cesar Lima Peres 1,2,3*, Kátia Regina Benati2,3, \\ Alessandra Rodrigues S. de Andrade2,3, Marcos Vinicius Alvim Guimarães², \\ Tércio da Silva Melo², Antonio Domingo Brescovit4, Jacques Hubert Charles Delabie ${ }^{3,5}$ \\ ${ }^{1}$ Territorial Planning and Social Development, Catholic University of Salvador, Salvador, Brazil \\ ${ }^{2}$ Ecology Center and Animal Conservation, Universidade Católica do Salvador, Salvador, Brazil \\ ${ }^{3}$ Federal University of Bahia, Salvador, Brazil \\ ${ }^{4}$ Butantan Institute, Collections Zoological Laboratory, São Paulo, Brazil \\ ${ }^{5}$ Laboratory of Myrmecology, UESC/CEPLAC, Centre for Cocoa Research, Ilhéus, Brazil \\ Email: ${ }^{*}$ peresmcl@ig.com.br
}

Received 15 April 2014; revised 20 May 2014; accepted 27 May 2014

Copyright (C) 2014 by authors and Scientific Research Publishing Inc.

This work is licensed under the Creative Commons Attribution International License (CC BY).

http://creativecommons.org/licenses/by/4.0/

(c) (i) Open Access

\begin{abstract}
The study investigates the effect of spatial and temporal tree-fall gaps structure on spiders' assemblage in an Atlantic forest fragmented area in Brazil. It was conducted in the Michelin Ecological Preserve-REM (Bahia), 190 ha forest remnant. Samples were collected on leaf-litter (50 × 50 $\mathrm{cm}$ ) at five tree-fall gaps formations $\left(<150 \mathrm{~m}^{2}\right)$, within five adjacent primary forest and five inner edge parcels. During 16 months (between May 2009 and October 2012), $480 \mathrm{~m}^{2}$ leaf-litter samples were collected, from which spiders were extracted using mini-Winkler traps. The observed and estimated richness of spider's species was higher at the edge $(p<0.01)$. The habitat structures differ significantly among the three habitat types (MRPP, $p<0.01$ ) and also during the tree-fall gaps aging gradient (MRBP, $p<0.01$ ). There were significant differences on spiders' species composition, comparing the three habitats (MRPP, $p<0.05$ ). The composition of spider's species changed as tree-fall gaps aged (MRBP, $p<0.05$ ). We argue that the tree-fall gaps play, on a local scale, an important role in acting on the time-space distribution dynamics of spider's species assemblages, although the time effect should still be evaluated.
\end{abstract}

\section{Keywords}

Atlantic Forest, Edge Effect, Habitat Selection, Spatiotemporal Effect, Neotropical Fauna

\footnotetext{
${ }^{*}$ Corresponding author.
}

How to cite this paper: Peres, M.C.L., et al. (2014) Tree-Fall Gaps Effects on Spider (Araneae) Assemblages in an Atlantic Forest Landscape in Northeastern Brazil. Open Journal of Animal Sciences, 4, 118-133. 


\section{Introduction}

Natural disturbances role in shaping the tropical forests biological communities' structure is widely known [1]. Natural disturbances increase habitat heterogeneity by promoting specialization and resource partitioning among species, whereas at the same time, they prevent from competitive exclusion fostering diversity [2]-[4]. Gaps formed by the fall of one or more trees are, apparently, the most common disturbance in forest environments, and these forms an opening in the canopy structure [5]. However, tree-fall gaps are likewise considered one of the main contributors for tropical forests' regeneration, significantly adding to its floristic diversity [6] [7], as they alter the habitat structure.

The regeneration witnessed on tree-fall gaps promotes the development of primary and pioneer species, and the secondary one promotes remarkable changes on trees' population's dynamics, species composition and growth rate [8] [9]. Therefore, it has been considered as an essential mechanism for the forests diversity's maintenance [3] [10] [11]. Tree-fall gap regeneration can be divided into three phases: tree-fall gaps formation, building phase, and mature phase [12]. These phases duration vary, and depend on factors such as size [6] [13], alleviation [14], severity of disturbance [13], soil condition [7] and pre-existing vegetation [15] [16].

The tree-fall gap phase is considered the most important to determine floristic composition [17], since it is characterized by an intense gap, changing microclimatic conditions and plant community structures [15]. It is estimated to last from four to six years in tropical forests [9].

Tree-fall gaps influence the spatial and temporal distribution of plants, therefore, affect these organisms' interactions to other animals [18] [19]. However, few studies have focused on animals, whilst most of them have pointed out structural aspects, such as area, age, geometry and type of fall, as well as vegetal organisms rather than their interactions [6] [10] [13]. This knowledge bulk has found significant tree-fall gaps influence on plant community structure. Following a thorough literature review we can refer to: studies on trees [3], pioneer plants [6] [14], bamboos [20], seedling growth [21], and gap and grazing areas interactions with the establishment, growth and survival of pioneer species [22].

Previous studies of animal related tree-fall gaps include: birds [1], ants [23]-[25] and spiders [26] [27]. No significant differences were found, on the aforementioned publications, between tree-fall gaps and mature forests on birds and orb-weaver spiders' studies. However, studies on ants have revealed controversial results. In a forest in India, species richness differed between forest tree-fall formations [23], whilst in a study conducted in a forest in Panama, no difference was found on species' abundance, richness and composition [24]. More recently, a study in a forest in Costa Rica found that the estimated richness differ between mature forest and adjacent tree-fall gap, although species composition did not show significant difference [25]. Most studies tend to compare the fauna in young tree-fall gaps to intact forest, ignoring that tree-fall gaps may change over time [25]. Thus, time scale approaches are essential to understand the tree-fall gaps dynamics, especially when related to certain animal groups such as arachnids.

Spiders (Arachnida: Araneae) are among the most abundant and diverse animal group, with 44,540 species currently described in the World [28]. They act as secondary predators on the trophic structure where they have a role [29]. They then, directly or indirectly regulate important taxa' abundance of ecosystem processes, such as predation, pollination, decomposition and dispersion [30]. Spiders' distribution and density are related to environmental factors such as temperature, relative humidity and luminosity [31] [32], habitat physiognomy, plant richness and composition [33]. In tropical forests such as any other natural landscape, habitat structure influences the richness and composition of spider's assemblages species [34]). Leaf litter structure also affects spiders' abundance [35], richness and composition [36] [37]. Therefore, natural disturbance caused by tree fall gaps may also influence the spider's assemblages [38] [39].

This study investigates whether tree-fall gaps show time-space scale effect on composition of spider's assemblages species in an Atlantic forest remnant at the Michelin Ecological Reserve, Igrapiúna, Bahia, northeastern Brazil. We addressed four questions: 1) Does the habitat structure of tree-fall gap (microclimate and microhabitat) significantly differ from that found in adjacent mature forest and inner edge? 2) Does the richness and composition of tree-fall gap species significantly differ from those found in adjacent mature forest and inner edge? 3) Does the habitat structure of natural tree-fall gaps (microclimate and microhabitat) significantly change during vegetation regeneration process? 4) Does the spider's species' assemblage composition of tree-fall gaps significantly change throughout the regeneration process? 


\section{Material \& Methods}

\subsection{Study Area}

The study was conducted at the Ecological Reserve Michelin (REM) (13 $50^{\circ} \mathrm{S}, 39^{\circ} 10^{\prime} \mathrm{W}, 90$ to $383 \mathrm{~m}$ above sea level), situated in the city of Igrapiúna and Ituberá (state of Bahia, Brazil). It is located $18 \mathrm{~km}$ away from the coast in a region known as "BaixoSul", $200 \mathrm{~km}$ south from the State capital city of Salvador. The 3096 ha REM area consists of a vegetation mosaic on different successional stages. Landscape id modified by different types of human disturbance, agriculture and pasture converted. And other forms of anthropogenic pressure (such as logging, hunting and exploitation of the palm). Approximately, $25 \%$ of the reserve is intended to rubber tree monoculture plantations [40]. The mean annual rainfall is $2000 \mathrm{~mm}$ and the temperature ranges from $21^{\circ} \mathrm{C}$ to $28^{\circ} \mathrm{C}$. [40].

The reserve contains 1800 ha of lowland evergreen hill forest distributed in three main fragments: Vila 5/Pancada Grande fragment with 625 ha, the 140 ha Luis Inácio forest, and the 550 ha Pacangê forest, which is contiguous with a 13,000 ha forest [40]. This study was conducted in Mata da Vila Cinco with 190 ha, which is one of the remnants. The northern access to this fragment is constituted by a land mosaic dominated by mature and young primary forest, where the canopy reaches uniformly from $18-25 \mathrm{~m}$. The southern access consists of mature second-growth forest, with trees ranging from eight to $13 \mathrm{~m}$ height, abundant vines and thick leaf litter. At higher slopes in the landscape there is a group of mature primary forest with several old trees. The local jussarapalm, bromeliads, vines and other epiphytes are abundant and well distributed in this remnant, which is crossed by a small river, two streams and several springs. The forest is surrounded by cocoa, rubber and banana plantations and is limited to the north by the "Mata do Rio" forest, another section of the reserve (K. Flesher, pers. comm.).

\subsection{Sampling Design}

Eight field surveys were conducted every two months, from July 2009 to October 2010. On the northern sector of Mata Vila Cinco we defined the tree-fall gaps and forest sampling points, both in the mature forest sections. In the mature forest stretches and along the main footpath edge sample points were set. The mature forest vegetation patch presents continuous canopy ranging from 18 and $25 \mathrm{~m}$. Most trees had their Diameter at breast height (DBH ) above $25 \mathrm{~cm}$, moderate frequency of vines, moderate to high density of bromeliads and other epiphytes, abundant palm trees and moderately dense herbaceous vegetation [40]. We initially found 25 tree-fall gaps, originated from natural tree-fall, with similar structure in relation to: 1) age group: gaps with no more than two months of formation i.e., the treetops still had the antlers with green leaves [14]; 2) origin: by uprooting [41]; 3) area: minimum area of $25 \mathrm{~m}^{2}$,estimation based on Runkle (1981); 4) adjacent canopy height: visual estimation [14], thus tree-fall gaps had similar height; and 5) size class: $\left(150 \mathrm{~m}^{2}\right)$ [41]. Among the 25 gaps, we selected the five most recent in the mature forest. The minimum distance between the five tree-fall gaps of $150 \mathrm{~m}$.

Having selected the five tree-fall gaps, we located the edge and forest sampling points. We established five forest's points in the stretch of primary forest, adjacent to the tree-fall gaps sampling points. We seek for points with no evidence of natural disturbance and which could characterize them as tree-fall gaps. We finally set the edge sampling points on the secondary-growth mature forest and distributed along the forest main footpath margin. After the selection of the 15 sampling points (SPs): five tree-fall gaps, five forest areas, and five edges, we then selected a $50 \mathrm{~m}^{2}$ parcel within each SP. Each parcel was them randomly sampled applying four $50 \times 50 \mathrm{~cm}$ quadrats in order to collect all the environmental metrics. In these parcels, we measured environmental metrics (microclimate and microhabitat) and we sampled spiders simultaneously as described below.

\subsection{Environmental Metrics (Microclimate and Microhabitat)}

In order to characterize the tree-fall gaps, forest and edges environmental structure, we measured during the eight survey occasions, the environmental microhabitat and microclimate variables: 1) temperature and relative air moist (range); 2) soil temperature; 3) soil surface temperature; 4) leaf litter layer depth; 5) estimated leaf litter cover; 6) estimated herbaceous vegetation cover; 7) volume of rotten wood (logs and fallen trunks); and 8) light intensity.

1) Temperature $\left({ }^{\circ} \mathrm{C}\right)$ and relative air moist $(\%)$ (range): metrics were taken at the center of the parcel, using a 
digital thermo hygrometer. The equipment was set on the vegetation, at about $150 \mathrm{~cm}$ from the soil surface during all the leaf litter sampling period. We measured the temperature and moist (maximum and minimum), within o ne hour interval and from these measurements we then calculated thermal range; 2) and 3) Soil and soil surface temperature of soil and substrate $\left({ }^{\circ} \mathrm{C}\right)$ : these measurements were taken in 4 locations inside each parcel, at the center of the four quadrats $(50 \times 50 \mathrm{~cm})$ where we collected the leaf-litter samples. To measure soil temperature we used a digital pen-type thermometer and for soil surface temperature, a digital infrared thermometer. The thermometer was then inserted in the soil; 4) Leaf-litter depth: These measurements were taken in cm, in the same fashion used for metrics two and three. In each quadrant $(50 \times 50 \mathrm{~cm})$, a plastic ruler was inserted until it reached the soil and the metric sampled; 5) and 6) Leaf-litter and herbaceous vegetation coverage Estimates: Fournier's adapted technique was applied to measure the percentage index of leaf-litter and vegetation cover. Acategorical quantification method, where values are assigned to categories: 1 - (covers $0 \%$ to $25 \%$ ), 2 - (26\% to 50\%), 3-(51\% to 75\%) and 4-(76\% to 100\%) [42]; 7) Decomposing fallen trunks and branches volume: Inside the $50 \mathrm{~m}^{2}$ parcels we measured the all branches and trunks ( $>5 \mathrm{~cm}$ circumference) length and circumference. From the circumference value $(\mathrm{m})$, we calculated the radius and using the formula $\left(\pi \times\right.$ radius $^{2} \times$ height), we then estimated the volume in $\mathrm{m}^{3}$. We finally, summed the values, obtaining the total volume $(\mathrm{m})$ of fallen trunks and branches with in each parcel; 8) Light intensity: these measurements were taken with a digital lux meter positioned at the center of each quadrat and 1 meter above the soil surface.

\subsection{Spider's Collection}

In order to survey spiders, we sampled leaf-litter and extracted the associated fauna using a mini-Winkler trap. We collected four $50 \times 50 \mathrm{~cm}$ leaf-litter samples of on each $50 \mathrm{~m}^{2}$ parcels of and placed them in the sieve and strained it. The resultant material remained in the mini-Winkler for $24 \mathrm{~h}$.

At each sampling survey occasion we took 60 leaf-litter samples, 20 in each sampling site (tree-fall gap, forest and edge), totalizing 480 leaf-litter samples over the eight surveys.

An additional night torching survey was applied [43]. A surveyor performed an active search in the $50 \mathrm{~m}^{2}$ parcels for 60 minutes, 30 minutes searching spiders on the leaf-litter, fallen trunks and branches, and 30 minutes on vertical vegetation up to $180 \mathrm{~cm}$. The spiders were captured with the use of forceps and fixed in alcohol $70 \%$. We conducted eight 15 hours sampling occasions, summing 120 hours of active search. Each parcel was treated as statistically different sampling unit.

The spiders were identified and deposited in the arachnid collection at the Instituto Butantan, Sao Paulo, Brazil (IBSP, curator: Dr. Irene Knysak). A portion of the biological material was deposited in the UFBA Zoology Museum, Salvador, Bahia, Brazil (MZUFBA, curator: Dr. Adolfo R. Calor).

\subsection{Statistical Analysis}

The following analysis was performed:

1) Spiders species richness was estimated with EstimateS 8.2.0 [44]. The data was randomized 50 times. The spiders' richness (observed and estimated) were compared between the three formations (tree-fall gaps, forest and edge) using the one-way ANOVA test (Graph PadInstat 3.0).

2) We used the matrices to compare species composition among the three vegetation formations (tree-fall gaps, forest and edge). To do so, we have applied a Multiple Response Permutation Procedure (MRPP)-(PC$\mathrm{ORD}^{\odot}$ 6.0) [45], using the Sorensen (Bray-Curtis) distance measure. The values were standardized (n/sum (n)) by program default and the significance level was set at 0.05 . Whereas we found a significant difference between the three vegetation types, we ran partial comparisons between sampling units. The MRPP is the most appropriated approach for community's studies since it not assumes multivariate normality and homogeneity of variances [46].

3) A tree-fall gap species composition matrix was created from the main sampling unit's formation matrix. This matrix was used to compare species composition among the tree fall gaps regeneration. In order to assess whether the spiders assemblage varied significantly over the tree-fall gaps regeneration, we compared four sub phases, between July 2009 and October 2010: Sub phase 1: July to September 2009, Sub phase 2: November 2009 to January 2010, Sub phase 3: March-May 2010 and Sub phase 4: August-October 2010. These sub phases are all included in the gap phase [12].

We applied the Blocked Multi-Response Permutation Procedures (MRBP)-(PCORD ${ }^{\odot}$ PC-6.0) [45] applying 
the Sorensen distance measure (Bray-Curtis). The MRBP (=MRPP in blocks), when design is in blocks, it is required a blocked analysis, such as MRBP, thus removing the effect of temporal dependence between samples [46]. The values were standardized (n/sum (n)) by the program default and the level of significance was set at 0.05. When significant differences were observed among the four sub phases, we ran partial comparisons.

4) To compare the habitat structure between the three formations (gaps, forest and edge) and along the regeneration of tree fall gaps we built microhabitat and microclimate variables matrices.

To make comparisons between the three formations, we extracted the mean of the data collected over the 16 field surveys and we applied the MRPP. In order to reach that we adopted the same procedures applied in item 3. To compare the four sub phases along their regeneration, we applied the MRBP (Blocked Multi-Response Permutation Procedures = MRPP in blocks). In order to obtain this we adopted the same procedures applied in item 4.

\section{Results}

The five selected tree-fall gaps presented areas between 86 and $110 \mathrm{~m}^{2}(\mathrm{sd}=11.09)$. The gaps were originated by uprooting, were recent and adjacent canopy height was estimated between 20 and $30 \mathrm{~m}$ (sd $=4.18$ ).

\subsection{Habitat Structure}

The habitat structure was significantly different between the three vegetation types tree-fall gaps, forest and edge (MRPP: $\mathrm{p}<0.001 ; \mathrm{T}=-32.642779, \mathrm{~A}=0.15145932$ ). When the habitat structure of the formations were pair wise compared, differences between them were also significant. Leaf-litter (depth and coverage) and relative air moist was higher in the forest. The herbaceous vegetation cover, the wood (logs and fallen branches) total volume, temperature (soil and substrate), thermal air and light range were higher in tree-fall gaps (Table 1 and Table 2).

Table 1. Mean and standard deviation (sd) of litter depth, litter cover, herbaceous cover and total volume of wood (fallen logs and branches) on decomposition. Standard deviation (sd) of tree-fall gap, adjacent forest and edges of Mata da Vila Cinco-Ecological Reserve Michelin (Igrapiúna-Bahia). Data collected between May 2009 and October 2012.

\begin{tabular}{cccc}
\hline Habitat Variables & Tree-fall gap & Forest & Edge \\
\hline Depth of litter $(\mathrm{cm})$ & $2.7( \pm 0.58)$ & $3.2( \pm 0.70)$ & $2.4( \pm 0.71)$ \\
Leaf Litter cover $^{*}$ & $3.5( \pm 0.64)$ & $3.9( \pm 0.35)$ & $3.4( \pm 0.67)$ \\
Herbaceous cover & \\
Total volume of fallen logs and branches $\left(\mathrm{m}^{3}\right)$ & $2.05( \pm 0.04)$ & $1.40( \pm 0.03)$ & $1.71( \pm 0.04)$ \\
\hline
\end{tabular}

* Measured in the scale of fournier.

Table 2. Mean and standard deviation (sd) of soil temperature, substrate temperature, air temperature range, relative air humidity and luminosity of tree-fall gap, adjacent forests and edges in Mata da Vila Cinco, Ecological Reserve Michelin (Igrapiúna-Bahia). Data collected between May 2009 and October 2012.

\begin{tabular}{cccc}
\hline Environmental variables & Tree-fall gap & Forest & Edge \\
\hline Soil temperature $\left({ }^{\circ} \mathrm{C}\right)$ & $23.8( \pm 1.88)$ & $23.6( \pm 1.51)$ & $23.8( \pm 1.34)$ \\
Substrate temperature $\left({ }^{\circ} \mathrm{C}\right)$ & $25.9( \pm 3.73)$ & $24.3( \pm 3.20)$ & $24.7( \pm 2.21)$ \\
Air temperature range $\left({ }^{\circ} \mathrm{C}\right)^{*}$ & $3.8( \pm 1.28)$ & $3.3( \pm 1.52)$ & $3.1( \pm 1.49)$ \\
Relative air humidity $(\%)$ & $73( \pm 10.78)$ & $76( \pm 10.14)$ & $74( \pm 10.20)$ \\
Luminosity & $4406( \pm 11,634)$ & $412( \pm 1444)$ & $2571( \pm 9181)$ \\
\hline
\end{tabular}




\subsection{Spider Assemblages}

A total of 4732 spiders, including juveniles and adults, divided into 41 families were collected. The most abundant families were Ctenidae (963-20.4\%), Araneidae (906-19.15\%) and Salticidae (534-11.3\%). Among the adult spiders, we recorded a total of 1179 individuals, comprising 126 species, belonging to 36 families. We registered 87 species in tree-fall gaps, 92 in forest and 90 on edges (Table 3). The richest families in species were: Araneidae (22 species-17.2\%), Theridiidae (18 species-14.1\%) and Ctenidae (12 species-9.4\%) (Figure 1).

Regarding the estimated species richness, the estimated value of the 2nd-order Jackknife (Jack 2) was the highest, indicating a richness of 185 species, whereas the Bootstrap showed the lowest estimates, with 140 species. The remaining estimators Estimates were similar to each other and showed intermediate Jack 1 and Bootstrap values. The estimated species accumulation curve and observed species curves, did not reach an asymptote for any of the three formations (Figure 2). There was no significant difference among the three formations in observed $(\mathrm{p}=0.7415, \mathrm{~F}=0.2998)$, estimated richness Jackknife $2(\mathrm{p}=0.6751, \mathrm{~F}=0.3942)$ and Bootstrap $(\mathrm{p}=$ $0.8094, \mathrm{~F}=0.2118$ ).

The first four field surveys (July 2009 to January 2010) data, when tree fall gaps reached eight months, we found significant differences in spiders, species composition, between the three vegetation formations (MRPP, $\mathrm{p}$ $=0.00398857, \mathrm{~A}=0.01368813, \mathrm{~T}=-3.0830481)$. However, when we compared the formations in pairs, no significant difference was found between tree-fall gaps and edges (Table 4). When data from the last four field surveys (March 2010 to October 2010), when the tree-fall gaps were between 10 to 16 months old, we found a significant difference in species composition of spiders among the three vegetation formations $(\mathrm{p}=0.0456, \mathrm{~A}=$ $0.0090, \mathrm{~T}=-1.8376$ ). However, when running pair wise comparisons among the formations, no significant difference was found between the tree-fall gaps and forest formations $(\mathrm{p}=0.8520, \mathrm{~A}=-0.0052, \mathrm{~T}=-1.005)$.

We recorded 10 (7.8\%) exclusive species in tree-fall gaps, 17 (13.3\%) in forests and $14(11.0 \%)$ on edges. However, in partial pair comparisons, these values were higher: tree-fall gaps vs. forest, presented respectively (19 unique species-14.9\%; 26\% - 20.3\%); forest vs edge, respectively (27 unique species-21.0\%; 24\% - 18.8\%) and tree-fall gaps vs. edge, respectively (20 unique species-15.6\%; 23\% - 18.0\%) (Table 4).

\subsection{Temporal Effect of Tree-Fall Gaps on Habitat Structure}

The habitat structure showed significant difference among the four gap sub phases $(\mathrm{MRBP}, \mathrm{p}=0.0056, \mathrm{~T}=$ -3.2479 , $A=0.1292)$. When sub phases were compared pair wise, significant differences were found only between sub phases ( 1 vs. 3 ) and (1 vs. 4) (Table 5).

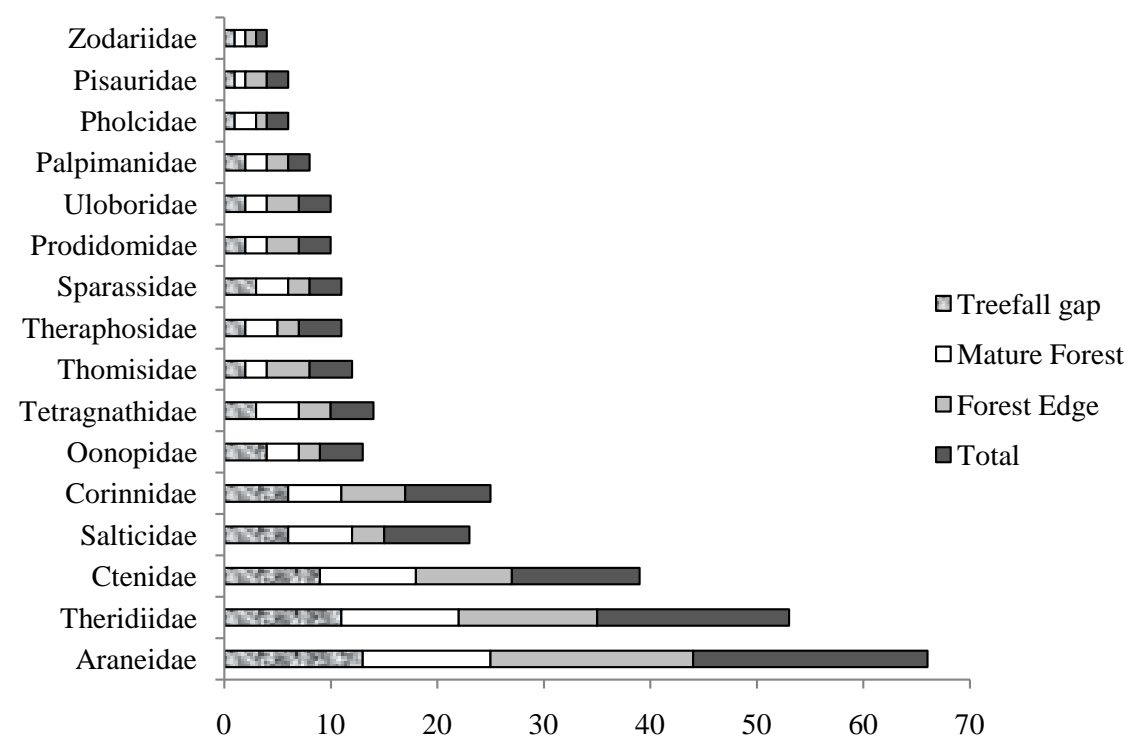

Figure 1. Species richness by family of spiders in Mata Vila Cinco-Ecological Reserve Michelin-REM (Igrapiúna-Bahia). We considered families representing at least $1 \%$ of total abundance. Data collected between May 2009 and October 2012. 
Table 3. Abundance of spider species in Mata da Vila Cinco-Ecological Reserve Michelin (Igrapiúna-Bahia). Data collected from July 2009 to October 2010.

\begin{tabular}{|c|c|c|c|c|}
\hline & Trefall gap & Mature forest & Forest edge & Total \\
\hline \multicolumn{5}{|l|}{ ANYPHAENIDAE } \\
\hline Hibana sp.1 & 1 & 2 & 0 & 3 \\
\hline Isigonia sp.1 & 2 & 2 & 1 & 5 \\
\hline \multicolumn{5}{|l|}{ ARANEIDAE } \\
\hline Acacesia sp.1 & 0 & 0 & 1 & 1 \\
\hline Alpaidagr. negra & 2 & 0 & 4 & 6 \\
\hline Alpaida delicata (Keyserling, 1892) & 1 & 1 & 1 & 3 \\
\hline Alpaida sp.1 & 11 & 14 & 14 & 39 \\
\hline Alpaida sp.2 & 0 & 0 & 1 & 1 \\
\hline Araneus sp.1 & 3 & 2 & 2 & 7 \\
\hline Cyclosa fililineata Hingston, 1932 & 2 & 0 & 1 & 3 \\
\hline Cyclosa sp.1 & 0 & 3 & 2 & 5 \\
\hline Dubiepeira sp.1 & 1 & 0 & 0 & 1 \\
\hline Eustala sp.1 & 6 & 2 & 5 & 13 \\
\hline Gasteracantha sp.1 & 0 & 0 & 1 & 1 \\
\hline Hypognatha sp.1 & 0 & 0 & 3 & 3 \\
\hline Kaira sp.1 & 0 & 0 & 1 & 1 \\
\hline Mangora sp.1 & 2 & 9 & 1 & 12 \\
\hline Melychiopharis sp.1 & 2 & 0 & 0 & 2 \\
\hline Metazygia sp.1 & 3 & 3 & 2 & 8 \\
\hline Micrathena sp.1 & 19 & 22 & 13 & 54 \\
\hline Micrathena sp.2 & 3 & 3 & 3 & 9 \\
\hline Micrathena sp.3 & 0 & 0 & 1 & 1 \\
\hline Ocrepeira sp.1 & 0 & 1 & 0 & 1 \\
\hline Parawixia sp.1 & 6 & 1 & 1 & 8 \\
\hline Wagneriana sp.1 & 0 & 2 & 1 & 3 \\
\hline \multicolumn{5}{|l|}{ CAPONIIDAE } \\
\hline Nops sp.1 & 1 & 1 & 1 & 3 \\
\hline \multicolumn{5}{|l|}{ CORINNIDAE } \\
\hline Castianeira sp.1 & 4 & 1 & 4 & 9 \\
\hline Corinna sp.1 & 7 & 10 & 10 & 27 \\
\hline Corinnidae sp.1 & 7 & 2 & 4 & 13 \\
\hline Ianduba sp.1 & 1 & 0 & 1 & 2 \\
\hline Myrmecium sp.1 & 1 & 0 & 0 & 1 \\
\hline Orthobula sp.1 & 3 & 5 & 2 & 10 \\
\hline
\end{tabular}




\section{Continued}

\begin{tabular}{|c|c|c|c|c|}
\hline Parachemmis sp.1 & 0 & 1 & 0 & 1 \\
\hline Stethorrhagus sp.1 & 0 & 0 & 2 & 2 \\
\hline \multicolumn{5}{|l|}{ CTENIDAE } \\
\hline Ancylometes rufus (Walckenaer, 1837) & 0 & 1 & 0 & 1 \\
\hline Celaetycheus sp.1 & 4 & 0 & 10 & 14 \\
\hline Ctenidae sp.1 & 1 & 2 & 2 & 5 \\
\hline Ctenus ornatus (Keyserling, 1877) & 0 & 4 & 4 & 8 \\
\hline Ctenus rectipes F. O. P. Cambridge, 1897 & 14 & 8 & 14 & 36 \\
\hline Ctenus sp.1 & 4 & 5 & 6 & 15 \\
\hline Enoploctenus cyclothorax (Bertkau, 1880) & 6 & 2 & 4 & 12 \\
\hline Enoploctenus maculipes Strand, 1909 & 1 & 0 & 0 & 1 \\
\hline Gephyroctenus sp.1 & 0 & 2 & 0 & 2 \\
\hline Isoctenus sp.1 & 4 & 10 & 9 & 23 \\
\hline Nothroctenus sp.1 & 5 & 3 & 6 & 14 \\
\hline Nothroctenus sp.2 & 1 & 0 & 3 & 4 \\
\hline \multicolumn{5}{|l|}{ CYRTAUCHENIIDAE } \\
\hline Cyrtaucheniidae sp.1 & 1 & 14 & 4 & 19 \\
\hline \multicolumn{5}{|l|}{ DEINOPIDAE } \\
\hline Deinopis sp.1 & 3 & 5 & 0 & 8 \\
\hline \multicolumn{5}{|l|}{ DIPLURIDAE } \\
\hline Masteria sp.1 & 5 & 2 & 3 & 10 \\
\hline \multicolumn{5}{|l|}{ GNAPHOSIDAE } \\
\hline Gnaphosidae sp.1 & 1 & 1 & 0 & 2 \\
\hline \multicolumn{5}{|l|}{ HERSILIIDAE } \\
\hline Ypypuera sp.1 & 4 & 8 & 5 & 17 \\
\hline \multicolumn{5}{|l|}{ IDIOPIDAE } \\
\hline Idiops sp.1 & 3 & 1 & 2 & 6 \\
\hline \multicolumn{5}{|l|}{ LINYPHIIDAE } \\
\hline Meioneta sp.1 & 5 & 3 & 1 & 9 \\
\hline \multicolumn{5}{|l|}{ LYCOSIDAE } \\
\hline Aglaoctenus sp.1 & 0 & 1 & 0 & 1 \\
\hline \multicolumn{5}{|l|}{ MIMETIDAE } \\
\hline Ero sp.1 & 0 & 1 & 0 & 1 \\
\hline Gelanor sp.1 & 1 & 3 & 6 & 10 \\
\hline \multicolumn{5}{|l|}{ MITURGIDAE } \\
\hline Eutichurus sp.1 & 0 & 0 & 1 & 1 \\
\hline
\end{tabular}




\section{Continued}

Miturgidae Gen. Novo

3

NEMESIIDAE

Nemesiidae gen.1

OCHYROCERATIDAE

Theotima sp.1

0

1

$0 \quad 1$

OECOBIIDAE

Oecobius sp.1

0

OONOPIDAE

aff. Oonops sp.1

Neoxyphinus sp.1

$$
\begin{aligned}
& \text { Oonops sp.1 } \\
& \text { Gr. Capitato }
\end{aligned}
$$

PALPIMANIDAE

Fernandezina sp.1

PHOLCIDAE

Carapoia sp.1

PISAURIDAE

Architis sp.1

Thaumasia sp.1

0

PRODIDOMIDAE

Lygromma sp.1

Lygromma sp.2

Lygromma sp.3

SALTICIDAE

Breda sp.1

Corythalia sp.1

Cotinusasp.1

Lyssomanes sp.1

Noegus sp.1

Salticidae sp.1

Salticidae sp.2

Thiodina sp.1

1

0

1

4

2

4

SCYTODIDAE

Scytodes sp.1

2

0 


\section{Continued}

\section{SENOCULIDAE}

Senoculus sp.1

1

1

\section{2}

4

SPARASSIDAE

Olios sp.1

Sparianthinae sp.1

Thomasettia sp.1

16

$19 \quad 8 \quad 43$

4

3

7

$0 \quad 11$

SYNOTAXIDAE

Synotaxus sp.1

0

3

3

9

TETRAGNATHIDAE

Aziliahistrio Simon, 1895

13

Chrysometa sp.1

Cyrtognatha sp.1

Leucauge sp.1

0

1

2

THERAPHOSIDAE

Ischnocolinae sp.1

Magulla sp.1

Plesiopelma sp.1

Theraphosidae sp.1

THERIDIIDAE

Achaearanea sp.1

Argyrodes elevatus Taczanowski, 1873

Argyrodes sp.1

Chrosiothes sp.1

Chrysso sp.1

Dipoena sp.1

Dipoena sp.2

Dipoena sp.3

Dipoena sp.4

Episinus gr. cognatus

Episinus sp.1

Episinus sp.2

Episinus sp.3

Euryopis sp.1

Nesticodes rufipes (Lucas, 1846)

Spintharus sp.1

Theridiidae sp.1

Theridion sp.1

0

0

1

1

0

0

0

7

3

1

0

3

10

1

0

1

0

10

0

4

4

1

1

3

3

$6 \quad 11$

$\begin{array}{lll}1 & 0 & 2 \\ 3 & 0 & 3 \\ 0 & 4 & 4 \\ 4 & 2 & 7\end{array}$

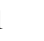

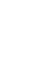

0

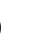

7

3

1

0

3

10

$1-2$

-

r

0

0

0

4

4

\begin{tabular}{lll}
0 & 0 & 1 \\
1 & 0 & 1 \\
1 & 1 & 2 \\
0 & 1 & 1 \\
4 & 3 & 14 \\
11 & 5 & 19 \\
0 & 1 & 2 \\
1 & 2 & 3 \\
0 & 3 & 6 \\
10 & 13 & 33 \\
9 & 10 & 20 \\
0 & 2 & 2 \\
1 & 2 & 4 \\
0 & 1 & 1 \\
1 & 0 & 11 \\
6 & 3 & 9 \\
2 & 1 & 7 \\
0 & 2 & 6 \\
\hline & &
\end{tabular}




\section{Continued}

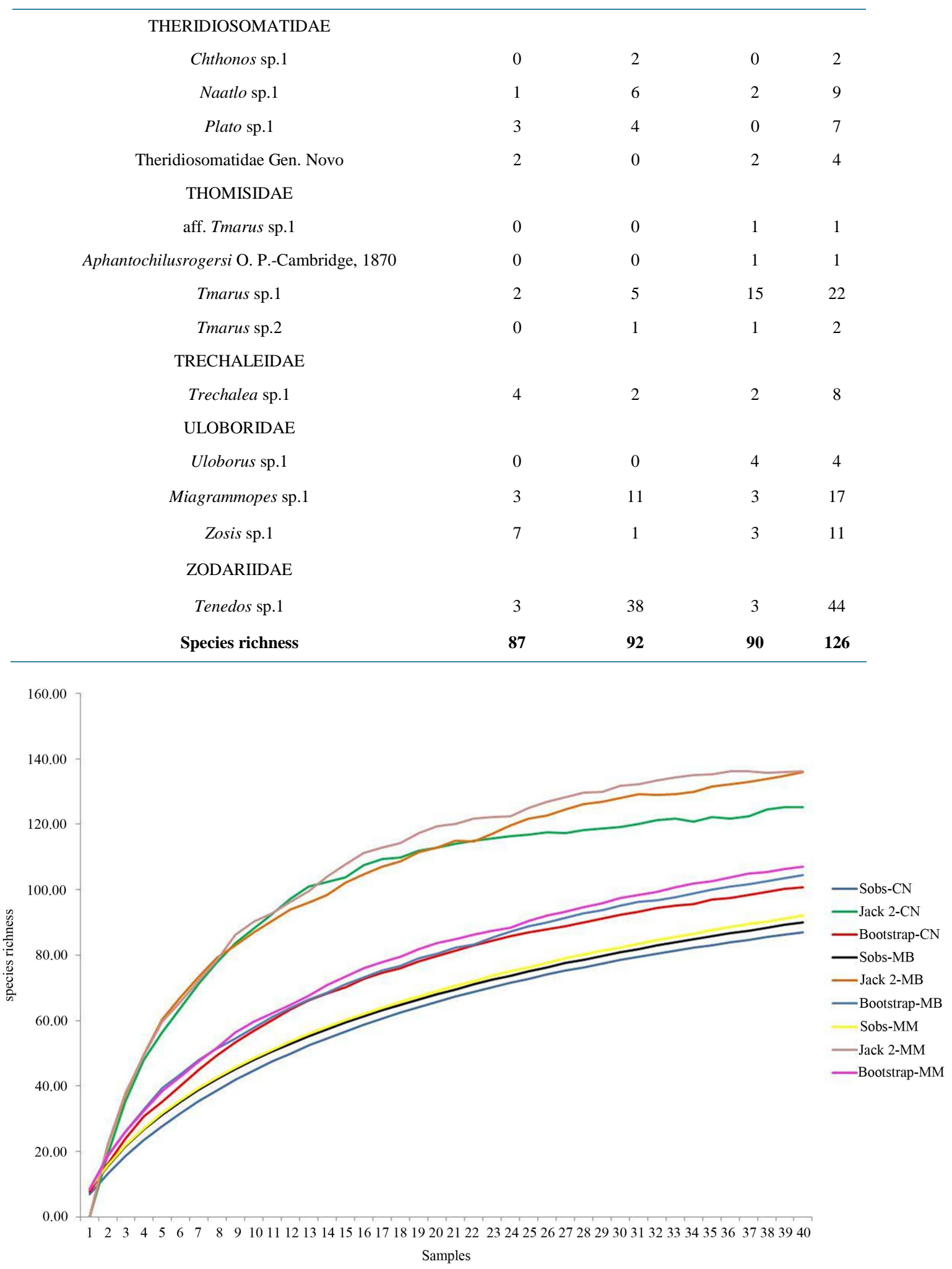

Figure 2. Estimates of species richness of spiders in the three formations: Tree-fall gap (TG), edge (FE) and forest (MF); in Mata Vila Cinco-Ecological Reserve Michelin-REM (Igrapiúna-Bahia). $\mathrm{S}_{\text {obs }}$ : Species observed. Estimated richness: Jack2 = 2nd order Jackknife. 
Table 4. Peer-to-peer comparisons spider species composition between vegetation formations: Tree-fall gap, forest and edges, considering the first four field campaigns in Mata da Vila Cinco-Ecological Reserve Michelin (Igrapiúna-Bahia). MRPP test (multi-response permutation procedure) $\mathrm{T}=$ variation between groups, $\mathrm{A}=$ variation within groups and $\mathrm{p}=$ statistical significance. US = number of exclusive species in the peer-to-peer comparisons. The bold letters are statistically significant values.

\begin{tabular}{ccccc}
\hline & T & A & p & US \\
\hline Tree-fall gap vs. Edge & -1.671 & 0.0079 & 0.0608 & 20 and 23 \\
Tree-fall gap vs. Forest & -1.830 & 0.0827 & 0.0470 & 19 and 26 \\
Edge vs. Forest & -3.053 & 0.0152 & 0.0059 & 24 and 27 \\
\hline
\end{tabular}

Table 5. Peer-to-peer comparisons of habitat structure among the four sub phases of a treefall gap in Mata of Vila Cinco-Ecological Reserve Michelin (Igrapiúna-Bahia). MRBP (Blocked Multi-Response Permutation Procedures): $\mathrm{T}$ = variation between groups; $\mathrm{A}=$ variation within groups and $\mathrm{p}=$ statistical significance. The bold letters are statistically significant values.

\begin{tabular}{ccccc}
\hline Sub phases & Estimated age (in months) $^{*}$ & T & A & p \\
\hline 1 vs. 2 & 4 vs. 8 & -1.247 & 0.0692 & 0.1107 \\
1 vs. 3 & 4 vs. 12 & -1.986 & 0.1167 & $\mathbf{0 . 0 4 7 7}$ \\
1 vs. 4 & 4 vs. 16 & -2.313 & 0.1732 & $\mathbf{0 . 0 3 3 9}$ \\
2 vs. 3 & 8 vs. 12 & -0.249 & 0.0064 & 0.3910 \\
2 vs. 4 & 8 vs. 16 & -0.989 & 0.0630 & 0.1420 \\
3 vs. 4 & 12 vs. 16 & -1.358 & 0.1280 & 0.0973 \\
\hline
\end{tabular}

*Maximum estimated age.

\subsection{Temporal Effect of Tree-Fall Gaps on Spider Assemblages}

The spider species' composition differ significantly among the four sub phases (MRBP, $p=0.0047, T=-3.007$, $A=0.2994)$. When we compared the sub phases pair wise, we found significant differences only between the sub phase four and the other sub phases (Table 6).

\section{Discussion}

\subsection{Habitat Structure}

The tree-fall gaps formations in fact promoted significant changes in environmental structure in relation to the adjacent forest, specifically in relation to microclimatic and microhabitat variables. Such differences have been reported in several studies in tropical forests [1] [15] [24]-[26] [47] [48]. We also found that throughout the regeneration within tree-fall gaps, major changes in habitat structure occurred, as reported on other studies [49] [50]. Moreover, the gradual closure of canopy promotes microclimate changes in areas originally open [19] [50]. Thus, our results confirm the role of natural disturbances in increasing habitat heterogeneity in time-spatial scales [2]-[4].

\subsection{Spiders' Assemblage}

The tree-fall gaps formation triggered significant changes in the spiders' assemblage in relation to the adjacent forest. This differentiation was observed in habitat structure and thus corroborated the association of spider assemblage's with microclimate and microhabitat variables, as reported by other studies. The habitat structure influence the spider's species' assemblages' composition and/or richness [26] [34] [36] [37]. The remarkable changes printed by canopy openings on luminosity, moist and temperature in the interior of tree-fall gaps affect spiders' population distribution and density, since they are closely associated with these environmental factors [26] [31] [32]. Changes in vegetation density also promote alterations in spiders' richness and diversity [51] [52]. 
Table 6. Peer-to-peer comparisons of spider species composition among the four sub phases in tree-fall gaps in Mata da Vila Cinco-Ecological Reserve Michelin (Igrapiúna-Bahia). MRBP test (Multiple-response Blocked Procedure): $\mathrm{T}=$ variation between groups, $\mathrm{A}=$ variation within groups and $\mathrm{p}=$ statistical significance. In bold letters, statistically significant values.

\begin{tabular}{ccccc}
\hline Sub-phases & Estimated age (in months) & T & A & p \\
\hline 1 vs. 2 & 4 vs. 8 & -0.9087 & 0.0088 & 0.1765 \\
1 vs. 3 & 4 vs. 12 & 0.0363 & -0.0004 & 0.5229 \\
1 vs. 4 & 4 vs. 16 & -2.4134 & 0.0454 & $\mathbf{0 . 0 2 0 0}$ \\
2 vs. 3 & 8 vs. 12 & -0.0153 & 0.0001 & 0.4832 \\
2 vs. 4 & 8 vs. 16 & -1.9200 & 0.0199 & $\mathbf{0 . 0 3 5 7}$ \\
3 vs. 4 & 12 vs. 16 & -2.7010 & 0.05411 & $\mathbf{0 . 0 1 5 7}$ \\
\hline
\end{tabular}

* Maximum estimated age.

Higher habitat heterogeneity allows orb-weaver spiders' occurrence, since this habitat quality increases the shelter offer for species settlement [53]. The orb-weavers Araneidae, Linyphiidae and Tetragnathidae families also showed strong dependence on relative air humidity [54]. These three families represent over $20 \%$ of the collected spiders, where Araneidae family was the richest. They also showed similar abundance in the three formations; however the highest number of exclusive species occurred in the forest. Indeed, richness in the forest was four times higher than in tree fall gaps and eight times higher than on edges. Dominance of forest exclusive orb-weaver spiders can be related to more stable microclimatic conditions found under more closed canopy.

Certainly, light in tree-fall gaps is the main variable that controls microclimate and other variables that make tree-fall gaps different from adjacent forest [10]. Another study compared tree-fall gaps in the Brazilian Northeast and adjacent forest showed that orb-weaver spiders exhibited preference for forest formations [26]. The high abundance of the Ctenidae spiders' family can be partially explained, because the size and intensity of bright in their eyes make them more conspicuous when sampling [55], which may have biased the effort. These spiders do not spin webs and many species of Ctenus actively forage on leaf-litter and vegetation [56], and also use the vegetation to molt [personal observation]. These spiders' higher abundance in the forest formation is associated with lower fallen trunks frequency [55], and higher moist [57]. Differences in leaf-litter structure and herbaceous cover between the three formations can also explain differences found in spider assemblages, since vegetation richness positively influence orb-weavers spiders' abundance [58] and plant density affects richness and diversity [51] [52]. Finally, habitat heterogeneity can increase spider's richness and thus favoring the occurrence of orb-weaver species [53].

The leaf-litter complexity affects the spider assemblages [37] [59]; a study conducted in a deciduous forest revealed that spiders are stratified distributed on leaf-litter [60]. Thus, a thicker leaf-litter on forest formations offers spiders' greater refuge and prey availability [35] [59]; favoring vertical distribution [60], and thus reducing competition. Furthermore, thicker leaf-litter reduces thermal amplitude and increases moist [61], creating microclimatic conditions with positive effect on spider's assemblages [31].

In contrast, higher luminosity in tree-fall gaps and edges promotes greater herbaceous vegetation cover, also contributing to increase of herbivores [62], important spiders' prey that forage on the foliage (Churchill, 1997). Besides, high coverage of herbaceous vegetation and fallen trunks in tree-fall gaps and edges boosts suitable supports for fixing the webs [63]. Therefore, tree-fall gaps, forest and edges have different habitat structure, marked by singularities on microclimate and microhabitat variables which in turn can have positive or negative associations with spiders, and therefore harbor distinct assemblages.

\section{Conclusion}

In conclusion, tree-fall gaps, even the small ones, have a crucial role in the dynamics of spider's assemblages in the Atlantic forest. The spatial effect is pronounced but the temporal effect, although detected by in the spiders' assembly, should be evaluated in the long-term ( $>4$ years). 


\section{Acknowledgments}

The authors are grateful to the Ecological Reserve Michelin for their excellent support, by providing us with necessary infrastructure and logistics during field campaigns. To Lacerta Ambiental by lending field equipment. M. C. L. P. is supported by Programa de Regime de Tempo Contínuo (RTC) of Universidade Católica do Salvador. J.H.C.D. is a CNPq fellow.

\section{References}

[1] Levey, D.J. (1988) Tropical Wet Forest Tree-fall Gaps and Distributions of Understory Birds and Plants. Ecology, 69, 1076-1089. http://dx.doi.org/10.2307/1941263

[2] Connell, J.H. (1978) Diversity in Tropical Rain Forests and Coral Reefs. Science, New Series, 199, 1302-1310.

[3] Denslow, J.S. (1980) Gap Partitioning among Tropical Rain Forest Trees. Biotropica, 12, 47-55. http://dx.doi.org/10.2307/2388156

[4] Pickett, S.T. and White, P.S. (1985) The Ecology of Natural Disturbances and Patch Dynamics. Academic Press, New York.

[5] Green, P.T. (1996) Canopy Gaps in Rain Forest on Christmas Island, Indian Ocean: Size Distribution and Methods of Measurement. Journal of Tropical Ecology, 12, 427-434. http://dx.doi.org/10.1017/S0266467400009639

[6] Brokaw, N.V.L. (1982) The Definition of Tree-Fall Gap and Its Effect on Measures of Forest Dynamics. Biotropica, 14, 158-160. http://dx.doi.org/10.2307/2387750

[7] Denslow, J.S. and Hartshorn, G.S. (1994) Tree-Fall Gap Environments and Forest Dynamic Process. In: McDade, L.A., Bawa, K.S., Hespenheide, H.A. and Hartshorn, G.S., Eds., La Selva-Ecology and Natural History of a Neotropical Rain Forest, The University of Chicago Press, Chicago, 120-127.

[8] Brokaw, N.V.L. (1985) Gap-Phase Regeneration in a Tropical Forest. Ecology, 66, 682-687. http://dx.doi.org/10.2307/1940529

[9] Fraver, S., Brokaw, N.V.L., Smith, A.P. and Box, P.O. (1998) Delimiting the Gap Phase in the Growth Cycle of a Panamanian Forest. Journal of Tropical Ecology, 14, 673-681. http://dx.doi.org/10.1017/S0266467498000479

[10] Whitmore, T.C. (1996) A Review of Some Aspects of Tropical Rain Forest Seedling Ecology with Suggestion for Further Enquiry. In: Swaine, M.D., Ed., The Ecology of Tropical Forest Tree Seedlings, UNESCO/Parthenon, Paris, 3-39.

[11] Schnitzer, S.A. and Carson, W.P. (2001) Tree-Fall Gaps and the Maintenance of Species Diversity in a Tropical Forest. Ecology, 82, 913-919. http://dx.doi.org/10.1890/0012-9658(2001)082[0913:TGATMO]2.0.CO;2

[12] Whitmore, T.C. (1990) An Introduction to Tropical Rain Forests. Oxford University Press, New York.

[13] Runkle, J.R. (1985) Disturbance Regimes in Temperate Forests. In: Pickett, S.T. and White, P.S., Eds. The Ecology of Natural Disturbance and Patch Dynamics, Academic Press, New York, 17-33.

[14] Tabarelli, M. and Mantovani, W. (1999) Clareiras naturais e a riqueza de espécies pioneiras em Floresta Atlântica Montana. RevistaBrasileira de Biologia, 59, 251-261. http://dx.doi.org/10.1590/S0034-71081999000200009

[15] Hubbell, S.P and Foster, R.B. (1986) Canopy Gaps and the Dynamics of a Neotropical Forest. In: Crawley, M.J., Ed., Plant Ecology, Blackwell, Oxford, 77-96.

[16] Dalling, J.W., Hubbell, S.P. and Silvera, K. (1998) Seed Dispersal, Seedling Establishment and Gap Partitioning among Tropical Pioneer Trees. Journal of Ecology, 86, 674-689. http://dx.doi.org/10.1046/j.1365-2745.1998.00298.x

[17] Whitmore, T.C. (1989) Canopy Gaps and the Two Major Groups of Forest Trees. Ecology, 70, 536-538. http://dx.doi.org/10.2307/1940195

[18] Thompson, J.N. (1980) Tree-Falls and Colonization Patterns of Temperate Forest Herbs. American Midland Naturalist, 104, 176-184. http://dx.doi.org/10.2307/2424969

[19] Dunn, R.R. (2004) Recovery of Faunal Communities during Tropical Forest Regeneration. Conservation Biology, 18, 302-309. http://dx.doi.org/10.1111/j.1523-1739.2004.00151.x

[20] Tabarelli, M. and Mantovani, W. (2000) Gap-Phase Regeneration in a Tropical Montane Rain Forest: The Effects of Gap Structure and Bamboo Species. Plant Ecology, 148, 149-155. http://dx.doi.org/10.1023/A:1009823510688

[21] Brown, N. (1996) A Gradient of Seedling Growth from the Centre of a Tropical Rain Forest Canopy Gap. Forest Ecology and Management, 82, 239-244. http://dx.doi.org/10.1016/0378-1127(95)03679-2

[22] Pearson, T.R.H., Burslem, D.F.P., Goeriz, R.E. and Dalling, J.W. (2003) Interactions of Gap Size and Herbivory on Establishment, Growth and Survival of Three Species of Neotropical Pioneer Trees. Journal of Ecology, 91, 785-796. http://dx.doi.org/10.1046/j.1365-2745.2003.00803.x 
[23] Basu, P. (1997) Seasonal and Spatial Patterns in Ground Foraging Ants in a Rain Forest in the Western Ghats, India. Biotropica, 29, 489-500. http://dx.doi.org/10.1111/j.1744-7429.1997.tb00043.x

[24] Feener Jr., D.H. and Schupp, E.W. (1998) Effect of Tree-Fall Gaps on the Patchiness and Species Richness of Neotropical Ant Assemblages. Oecologia, 116, 191-201. http://dx.doi.org/10.1007/s004420050579

[25] Patrick, M., Fowler, D., Dunn, R.R. and Sanders, N.J. (2012) Effects of Tree-Fall Gap Disturbances on Ant Assemblages in a Tropical Montane Cloud Forest. Biotropica, 44, 472-478. http://dx.doi.org/10.1111/j.1744-7429.2012.00855.x

[26] Peres, M.C.L., da Silva, J.M.C. and Brescovit, A.D. (2007) The Influence of Tree-Fall Gaps on the Distribution of Web Building and Ground Hunter Spiders in an Atlantic Forest Remnant, Northeastern Brazil. Studies on Neotropical Fauna and Environment, 42, 49-60. http://dx.doi.org/10.1080/01650520600891889

[27] Peres, M.C.L., Souza-Alves, J.P., Benati, K.R., Dias, M.A., Alves, A.O., Máximo, C.O. and Brescovit, A.D. (2010) Distribution of Leaf Litter Spider (Araneae) in Tree-Fall Gaps and on Adjacent Forest in an Atlantic Rainforest Remnant in Bahia State, Brazil. Revista Biociências, 16, 109-115.

[28] Platnick, N.I. (2014) The World Spider Catalog, Version 12.5. http://research.amnh.org/iz/spiders/catalog/COUNTS.html

[29] Riechert, S.E. and Bishop, L. (1990) Prey Control by an Assemblage of Generalist Predators: Spiders in a Garden Test System. Ecology, 71, 1441-1450. http://dx.doi.org/10.2307/1938281

[30] Churchil, T.B. (1997) Spiders as Ecological Indicators: An Overview for Australia. Memoirs of the Museum of Victoria, 56, 331-337.

[31] Huhta, V. (1971) Succession in the Spider Communities of the Forest Floor after Clear-Cutting and Prescribed Burning. Annales Zoologici Fennici, 8, 483-542.

[32] Rypstra, A.L. (1986) Web Spiders in Temperate and Tropical Forests, Relative Abundance and Environmental Correlates. American Midland Naturalist, 115, 42-51. http://dx.doi.org/10.2307/2425835

[33] Toti, D.S., Coyle, F.A. and Miller, J.A. (2000) A Structured Inventory of Appalachian Grass Bald and Heath Bald Spider Assemblages and a Test of Species Richness Estimator Performance. Journal of Arachnology, 28, 329-345. http://dx.doi.org/10.1636/0161-8202(2000)028[0329:ASIOAG]2.0.CO;2

[34] Uetz, G.W. (1991) Habitat Structure and Spider Foraging. In: Bell, S.A., McCoy, E.D. and Mushinsky, H.R., Eds., Habitat Structure, the Physical Arrangement of Objects in Space, Chapman \& Hall Press, London, 325-348. http://dx.doi.org/10.1007/978-94-011-3076-9_16

[35] Bultman, T.L. and Uetz, G.W. (1984) Effect of Structure and Nutritional Qualify Litter on Abundances of LitterDwelling Arthropods. American Midland Naturalist, 111, 165-172. http://dx.doi.org/10.2307/2425555

[36] Benati, K.R., Peres, M.C.L., Tinoco, M.S. and Brescovit, A.D. (2010) Influência da estrutura de hábitat sobre aranhas (Araneae) de serrapilheira em dois pequenos fragmentos de mata atlântica. Neotropical Biology and Conservation, $\mathbf{5}$, 39-46. http://dx.doi.org/10.4013/nbc.2010.51.06

[37] Benati, K., Peres, M., Brescovit, A., Santana, F. and Delabie, J. (2011) Avaliação de duas técnicas de translocação de serrapilheira sobre as assembleias de aranhas (Arachnida: Araneae) e formigas (Hymenoptera: Formicidae). Neotropical Biology and Conservation, 6, 13-26. http://dx.doi.org/10.4013/nbc.2011.61.03

[38] Coley, P.D., Bryant, J.P. and Chapin, F.S. (1985) Resource Availability and Plant Anti Herbivore Defense. Science, 230, 895-899. http://dx.doi.org/10.1126/science.230.4728.895

[39] Kowal, V. and Cartar, R.V. (2011) Edge Effects of Three Anthropogenic Disturbances on Spider Communities in Alberta's Boreal Forest. Journal of Insect Conservation, 2, 1-15.

[40] Flesher, K.M. and Laufer, J. (2013) Protecting Wildlife in a Heavily Hunted Biodiversity Hotspot: A Case Study from the Atlantic Forest of Bahia, Brazil. Tropical Conservation Science, 6, 181-200.

[41] Brokaw, N.V.L. (1982) Tree-Falls: Frequency, Time, and Consequences. In: Leight Jr., E.G., Rand, A.S. and Windsor, D.M., Eds., The Ecology of a Tropical Forest: Seasonal Rythms and Long-Term Changes, Smithsonian Institution Press, Washington DC, 101-108.

[42] Fournier, L.A. (1974) Un método cuantitativo para la medición de características fenólogicas en árboles. Turrialba, 24, 422-423.

[43] Coddington, J.A., Griswold, C.E., Davila, C.E., Penaranda, D.S. and Larcher, S.F. (1991) Designing and Testing Sampling Protocols to Estimate Biodiversity in Tropical Ecosystems. The Unity of Evolutionary Biology: Proceedings of the 4th International Congress of Systematic and Evolutionary Biology, Discorded Press, Portland, 44-60.

[44] Colwell, R.K. (2006) EstimateS: Statistical Estimation of Species Richness and Shared Species from Samples. http://purl.oclc.org/estimates

[45] Mccune, B. and Mefford, M.J. (1999) Multivariate Analysis of Ecological Data. Version 4.25, MjM Software, Glene- 
den Beach.

[46] Mccune, B. and Grace, J.B. (2002) Analysis of Ecological Communities. Mjm Software, Gleneden Beach.

[47] Hubbell, S.P. and Foster, R.B. (1986) Canopy Gaps and the Dynamics of a Neotropical Forest. In: Crawley, M.J., Ed., Plant Ecology, Blackwell, Oxford, 77-96.

[48] Whitmore, T.C., Brown, N.D., Swaine, M.D., Kennedy, D., Goodwin-Bailey, C.I. and Gong, W.K. (1993) Use of Hemispherical Photographs in Forest Ecology, Measurement of Gap Size and Radiation Totals in Bornean Tropical Rain Forest. Journal of Tropical Ecology, 9, 131-159. http://dx.doi.org/10.1017/S0266467400007112

[49] Brown, N. (1993) The Implications of Climate and Gap Microclimate for Seedling Growth Conditions in a Bornean Lowland Forest. Journal of Tropical Ecology, 9, 153-168. http://dx.doi.org/10.1017/S0266467400007136

[50] Palladini, J.D., Jones, M.G., Sanders, N.J. and Jules, D.E.S. (2007) The Recovery of Ant Communities in Regenerating Temperate Conifer Forest. Forest Ecology and Management, 242, 619-624. http://dx.doi.org/10.1016/j.foreco.2007.01.074

[51] Gunnarsson, B. (1990) Vegetation Structure and the Abundance and Size Distribution of Spruce-Living Spiders. Journal of Animal Ecology, 59, 743-752. http://dx.doi.org/10.2307/4892

[52] Halaj, J., Ross, D.W. and Moldenke, A.R. (1998) Habitat Structure and Prey Availability as Predictors of the Abundance and Community Organization of Spiders in Western Oregon Forest Canopies. Journal of Arachnology, 26, 203220.

[53] Simó, M., Laborda, A., Jorge, C. and Castro, M. (2011) Las arañas en agroecosistemas, bioindicadores terrestres de calidad ambiental. Revista Del Laboratorio Tecnológico Del Uruguay, INNOTEC, 51-55.

[54] Gillespie, R.G. (1987) The Mechanisms of Habitat Selection in Long-Jawed Orb-Weaving Spider Tetragnatha elongata (Araneae: Tetragnathidae). Journal of Arachnology, 15, 81-90.

[55] Rego, F.N.A.A. (2003) Efeitos da fragmentação sobre a comunidade de aranhas do Sub-bosque de uma floresta de Terra-firme, na Amazônia Central. MSc. Thesis, Universidade Federal do Amazonas, Manaus.

[56] Hofer, H., Brescovit, A.D. and Gasnier, T.R. (1994) The Wandering Spiders of the Genus Ctenus (Ctenidae: Araneae) of Reserva Ducke, a Rainforest in Central Amazonia. Andrias, 13, 81-89.

[57] Gasnier, T.R. and Höfer, H. (2001) Patterns of Abundance of Four Species of Wandering Spiders (Ctenidae: Ctenus) in a Forest in Central Amazonia. Journal of Arachnology, 29, 95-103. http://dx.doi.org/10.1636/0161-8202(2001)029[0095:POAOFS]2.0.CO;2

[58] Baldissera, R., Ganade, G. and Fontoura, S.B. (2004) Web Spider Community Response along an Edge between Pasture and Araucaria Forest. Biological Conservation, 118, 403-409. http://dx.doi.org/10.1016/j.biocon.2003.09.017

[59] Uetz, G.W. (1976) Gradient Analysis of Spider Communities in a Streamside Forest. Oecologia, 22, 373-385. http://dx.doi.org/10.1007/BF00345314

[60] Wagner, J.D., Toft, S. and Wise, D.H. (2003) Spatial Stratification in Litter Depth by Forest-Floor Spiders. Journal of Arachnology, 31, 28-39. http://dx.doi.org/10.1636/0161-8202(2003)031[0028:SSILDB]2.0.CO;2

[61] Gonzalez, G. and Zou, X. (1999) Plant Litter Influences on Earthworm Abundance and Community Structure in a Tropical Wet Forest. Biotropica, 31, 486-493. http://dx.doi.org/10.1111/j.1744-7429.1999.tb00391.x

[62] Harrison, S. (1987) Tree-Fall Gaps versus Forest Understory as Environments for a Defoliating Moth on a Tropical Forest Shrub. Oecologia, 72, 65-68. http://dx.doi.org/10.1007/BF00385046

[63] Coyle, F.A. (1981) Effects of Clear-Cutting on the Spider's Community of a Southern Appalachian Forest. Journal of Arachnology, 9, 285-298. 